\title{
On Crime and Punishment: Derrida Reading Kant
}

\author{
Jacques De Ville ${ }^{1}$
}

Published online: 10 December 2019

(c) Springer Nature B.V. 2019

\begin{abstract}
This essay enquires into the implications for criminal law of Derrida's analysis in the Death Penalty seminars. The seminars include a reading of Kant's Metaphysics of Morals, specifically Kant's reflections on the sovereign right to punish, which is read in conjunction with the reflections of Freud and Reik on the relation between the unconscious and crime, as well as Nietzsche's reflections on morality, punishment and cruelty. What comes to the fore in Derrida's analysis is a system of economic exchange operating on an unconscious level, of which criminal law forms an intrinsic part. Derrida's analysis of the 'origin' of crime in the seminars poses serious questions to the assumption of freedom underlying modern criminal law. The link, which he posits between punishment and political theology, likewise challenges the existing theories and forms of punishment. What the seminars call for, in the name of the Kantian Enlightenment, is a radical break with economic circularity as it operates in respect of crime and punishment.
\end{abstract}

Keywords Confession · Forgiveness $\cdot$ Freedom $\cdot$ Pleasure $\cdot$ Unconscious

Jacques De Ville

jdeville@uwc.ac.za

1 Law Faculty, University of the Western Cape, Private Bag X17, Bellville 7535, South Africa 
And you, scarlet judge, if you would speak aloud all you have done in thought, everyone would cry: 'Away with this filth and poisonous snake!' (Nietzsche 2003b, p. 65)

\section{Introduction}

Derrida's Death Penalty seminars, which ran from 1999 to 2000 and which have now been published in two volumes, challenge us to reflect again on our notions of crime and punishment. Kant's 'Doctrine of Law' ${ }^{1}$ in the Metaphysics of Morals stands central in Derrida's analysis. The section titled 'On the right to punish and to grant clemency', in Kant's Doctrine of Law deals with the power which the state has to punish the wrongdoer, the purpose of punishment, and the measure of punishment, specifically when the death penalty would be justifiable. Derrida provides a detailed analysis of this section, as well as of the section titled 'Further Discussion of the Concept of the Right to Punish' in the appendix of the 1798 edition of the Doctrine of Law, and in the present essay we will follow him closely to bring out the most important aspects of his analysis. We will see that Derrida's quasi-psychoanalytical reading of Kant consists partly of a defence of Kant, partly of a critique and partly of a deconstruction. In Derrida's seminars, Freud and Reik, as well as Derrida's own transformation of psychoanalysis in other texts, play an important role. Psychoanalysis was indeed influential in the criminal law field in certain jurisdictions during the late 1950s and early 1960s, that is, around the time of the appearance of the 1959 English translation of Reik's The Compulsion to Confess (Schmeiser 2007). That influence has however been in decline, perhaps partly because of a realisation that there would be no justification for criminal law should the claims of psychoanalysis be accepted (Schmeiser 2007, pp. 318, 331). The same conclusion appears to follow from Derrida's seminars, which in broad terms show the tenuous nature of the basic principles of criminal justice, as well as the need to thoroughly revisit their premises. As Derrida (2017, p. 9) puts it in the seminars, posing thereby a radical challenge to legal scholars: 'Up until now, the law has forbidden itself or has been unable to integrate into its essential axiomatic a logic of the unconscious or the symptom'.

The essay will start with an analysis of legal subjectivity and its relation to punishment. Here we will enquire into Kant's premise of freedom to establish criminal responsibility, and show how this is undermined by the analysis of Reik, but even more so by Derrida, in his analysis of a certain sexual desire and guilt at the origin of all crime. This will be followed by an analysis of the relation between sovereignty and punishment. Here we will see how Derrida shows with reference to Nietzsche and Freud the close relation between sovereignty, the drive to mastery, cruelty, and pleasure, thereby pointing to sovereignty's condition of possibility and

\footnotetext{
1 This section is usually translated as 'The Doctrine of Right [Der Rechtslehre]', but 'Law' appears contextually more appropriate.
} 
its phantasmatic nature. In looking at the purpose or theories of punishment, Kant, as we will see, rejects any kind of utilitarian argument in relation to punishment, specifically in respect of the death penalty. For Kant, punishment follows by virtue of the categorical imperative, in view of man's dignity, which he regards as having a value higher than life. Punishment, also the death penalty, is thus justified with reference to a certain concept of man, which Derrida traces back to political theology. We will see how Derrida seeks to explain what lies behind the abolitionist and pro-retention discourses on the death penalty, with reference to a conception of life which is not inspired by political theology. This will be followed by an analysis of the measurement to be used in respect of punishment according to Kant. We will see here how Derrida, in a very close reading, shows that there is actually a tension in Kant between a certain non-calculability and calculation. The essay will conclude by exploring the possibility of further reform of the foundational principles of criminal justice.

\section{Legal Responsibility and Punishment}

For Kant (2015, 6:331), punishment follows (only) after a court has found that someone has committed a crime. Although Kant does not spell this out in detail here, responsibility for a crime and liability for punishment in his thinking are tied to man's noumenal nature, i.e. his freedom from his natural inclinations, and thus his freedom as subject to choose (consciously) whether or not to commit a crime, as well as subsequently to be held responsible and liable should he have done so (Geismann 2012, pp. 127-128). Derrida (2017, p. 110) affirms this understanding of Kant and of modern criminal law in general, noting that 'what gives meaning to the concepts of offense, crime, punishment, and in particular the death penalty' is responsibility, guilt; in other words, the freedom and consciousness of the subject, of the subject as 'I', as a clear and unambiguous relation to its intention, to the intentionality of its acts, to its conscious will, to its power over itself, to the 'I can'.

In other words, as Derrida (2017, p. 210) also puts it, condemnation for a crime is tied to the notion of a free, responsible and guilty individual. ${ }^{2}$ The challenge posed to this Kantian account of homo noumenon comes primarily from psychoanalysis, which poses a radical threat to the credit we give to these concepts by questioning the self-identity of the subject, for example by showing the impact of the unconscious on consciousness, and, more specifically, by positing the notion of a death drive (Derrida 2017, p. 110). Theodor Reik contends in this regard that guilt or fault does not only accompany the crime as supposed by Kant and by modern criminal law, but that it precedes the crime by virtue of the Oedipus complex as internalised in the super-ego, and thus motivates the crime. The criminal in other words wants to be punished (to ease his guilt, and to satisfy his 'masochistic sexual trend'), and therefore commits a crime (Freud 2001 XVII p. 28; Reik 1959, pp. 292-293;

\footnotetext{
${ }^{2}$ See also Derrida (2017, p. 95).
} 
Derrida 2017, p. 38). ${ }^{3}$ Reik (1959, pp. 296-298) consequently proposes that legal punishment should be abolished, and be replaced by confession. In the seminars, Derrida confirms the importance of this psychoanalytical explanation as well as of the enquiry into alternatives for legal punishment. He does not however find this explanation fully convincing, and as we will see, seeks to take Reik's analysis in a different direction.

Reik's account is attractive because of the challenge it poses to the Kantian notion of freedom by way of the Oedipus complex lodged in the unconscious. The criminal, as we saw, commits a crime because he feels guilty, i.e. he has an unconscious feeling of guilt (murder of the father, incest with the mother). The crime is in other words 'reassuring for the one who feels guilty' (Derrida 2017, p. 181). In the words of Reik (1959, p. 292), '[c]rime is felt as emotional relief because it can connect the unconscious feeling of guilt to something real, actual'. ${ }^{4}$ This account follows upon the analysis of Freud (2001 XIII, pp. 1-161) in Totem and Taboo where he traced the origin of (criminal) law, and more specifically the taboos of murder and incest, back to the sons' killing of the father of the primal horde, and thus to the Oedipus complex. For Derrida (2017, pp. 3-7), psychoanalysis raises fundamental questions about age, act and desire. For example, what age should be relevant for deciding whether someone is criminally responsible? As it could very well be, assuming that Reik/Freud is right, that the crime is motivated by the unconscious Oedipus complex, which according to Freud develops in a child between the ages of three to five. ${ }^{5}$ Criminal law is furthermore concerned only with (wrongful) actions, tied to conscious intentions (or negligence), and not unconscious wishes and desires, thereby disregarding the very prevalent unconscious desire to kill (Derrida 2017, p. 80). In other words, criminal law seems to attach no importance to the fact that we are all murderers in terms of the unconscious, which according to Freud is no less real than a conscious, intentional, actual act (Derrida 2017, pp. 78-79). Should this not be central in thinking about crime and punishment? Derrida, as noted, is suspicious of the accounts of Freud and Reik as the unconscious here appears to remain within a circular economy (Derrida 2017, p. 170). Reik (1959, p. 425) specifically notes in this regard that ' $[\mathrm{t}] \mathrm{o}$ the unconscious, gratefulness is as foreign as is forgiveness'. The unconscious thus operates according to the talionic principle: it desires to punish, and to pay back; it knows no forgiveness and no mercy, no thanks, and no pardon (Derrida 2017, p. 170).

The questions of age, act and desire, the notion of the unconscious, the idea of auto or self-punishment and guilt, whether before, alongside or after the crime,

\footnotetext{
${ }^{3}$ Reik (1959) views the compulsion to confess and the closely related unconscious need for punishment as a general tendency, and thus detectable also beyond the field of criminal law. Examples would include a partner who is sexually unfaithful and leaves behind clues of his/her infidelity; a person who is constantly hostile towards relatives and friends, even though this causes suffering; and a child who acts naughtily, thereby seeking punishment.

${ }^{4}$ See further Reik (1959, p. 474).

${ }^{5}$ Derrida (2017, pp. 10-13) adds to this the relevance of other ages: mental age, social age, the agelessness of the unconscious, as well as the ages of human and animal life in general; see also Derrida and Roudinesco (2004, pp. 158-159).
} 
are arguably implicit in Kant $(2015,6: 331)$. This can be detected in the distinction he draws between external, hetero-, legal or public punishment by a court (poena forensis) and natural, inner, or self-punishment (poena naturalis), the latter which he notes is of no interest to the legislator (Derrida 2017, p. 37). As Derrida (2017, pp. 38-39) points out, the distinction between poena naturalis and poena forensis is undoubtedly an important one, but not one that is easy or possible to maintain in all rigour, especially not in view of Reik's analysis where, as we saw, guilt precedes the crime. Crime is therefore committed to give actuality to guilt, and self-punishment thereby becomes hetero-punishment. Conversely, the whole Kantian logic of legal rationality, whereby the laws enacted are supposed to be universally agreed to by citizens, necessarily entails that hetero-punishment also becomes auto-punishment (Derrida 2017, pp. 66-69, 98; Derrida and Roudinesco 2004, p. 150). ${ }^{6}$ We likewise see this logic reflected in Kant's description of punishment when he declares that

whatever undeserved evil you inflict upon another within the people, that you inflict upon yourself. If you insult him, you insult yourself; if you steal from him, you steal from yourself; if you strike him, you strike yourself; if you kill him, you kill yourself. (Kant 2015, 6:332) ${ }^{7}$

This convergence of auto- and hetero-punishment can furthermore play itself out in a variety of ways: the natural punishments that someone imposes on himself can be more severe than the legal punishments, and can add to these or precede them (Derrida 2017, p. 38). Furthermore, someone may feel so guilty after a crime, that he seeks legal punishment to alleviate the internal punishment (Derrida 2017, p. 38).

Let us return now to the question of freedom in Kant, as the foundational principle of criminal law. It should already be clear from the above account that things are not as simple as they seem. In For What Tomorrow Derrida casts doubt on the possibility of demonstrating, 'in all Kantian logic, that the crime was committed freely, in a responsible and not a "pathological" way, in both the Kantian and the common sense of this word' (Derrida and Roudinesco 2004, p. 152). We do not have space here to engage in a thorough analysis of Derrida's reading of Freud and Reik, but as already indicated above, there are certain clear difficulties in their analyses. This is due inter alia to the circular economy that still characterises the unconscious in Freud and Reik. We see this for example in Reik's positing of (guilt because of Oedipal) sexual desire as at the origin or as the motive of all crime (Reik 1959, p. 293). ${ }^{8}$ It is when the feeling of guilt becomes too intense, that the criminal seeks a substitute, a peg, to hang the guilt on (Reik 1959, pp. 292-293; Derrida 2017, pp. 181-182). ${ }^{9}$ Derrida agrees with this idea - that every crime is a sexual crime-in principle, but not with Reik's understanding of sex in an Oedipal sense (Derrida

\footnotetext{
6 See e.g. 'On the Common Saying' where Kant (1996, 8:297) speaks about the Idea of reason, that is, 'to bind every legislator to give his laws in such a way that they could have arisen from the united will of a whole people and to regard each subject, insofar as he wants to be a citizen, as if he has joined in voting for such a will'.

7 Derrida (2017, pp. 66-67) points out that this situation is portrayed by Kafka in America.

8 See likewise Freud (2001 XIV, pp. 332-333) (Criminals from a sense of guilt).

9 See also Freud (2001 XIV, pp. 332-333).
} 
2017, p. 181). ${ }^{10}$ The Oedipal scene, as Derrida points out, incidentally also plays itself out in The Metaphysics of Morals, with Kant regarding the putting to death of the sovereign, through a formal process, parricide in other words (parricida as Kant refers to it, 'the attempt to destroy his fatherland'), as the supreme crime, the crime par excellence, which deserves death (Kant 2015, 6:320; Derrida 2017, p. 188). ${ }^{11}$ The sovereign may thus not be judged or executed under any circumstances (Derrida 2017, p. 188). This is because he is the source and foundation of law (Derrida 2017, p. 188). Kant (2015, 6:320 note) puts the feeling that arises as a result of such parricide in very strong terms:

But how are we to explain this feeling, which is not aesthetic feeling (sympathy, an effect of imagination by which we put ourselves in the place of the sufferer) but moral feeling resulting from the complete overturning of all concepts of rights? It is regarded as a crime that remains forever and can never be expiated (crimen immortale, inexpiable), and it seems to be like what theologians call the sin that cannot be forgiven either in this world or the next....

Like a chasm that irretrievably swallows everything, the execution of a monarch seems to be a crime from which the people cannot be absolved, for it is as if the state commits suicide.

Derrida (2017, p. 191) refers to this notion of the suicide of the state as 'an autoimmune process', standing in tension with that which is immune, sacred, sovereign, untouchable. The formal execution of the monarch would be 'the phenomenon or at least the symptom of an autoimmune disaster: absolute desacralization, blasphemy that attacks the sacral body_-sacred and sacramental' (Derrida 2017, p. 192). However this abyssal suicide of the state never takes place as an actual event. As Derrida puts it, '[n]one of this takes place; it has no place taking place. None of this can actually happen. There can only be simulacra or phantasms of it' (Derrida 2017, p. 192). Derrida's comment follows in view of Kant's explanation that what motivates the (formal) parricide, the simulacra of a trial and punishment, is fear of the King returning to power and then taking vengeance on the people (Derrida 2017, p. 192). Similar to Freud and Reik, Kant thus seeks the motivation of this crime in a drive for vengeance. At stake for Derrida in the 'sexual' origin of all crime is however rather, as also alluded to by Kant, some 'suicide' or force of self-destruction beyond the Oedipus complex, beyond parricide, an event that never takes place, of pleasure without end (Derrida 1987, pp. 397-402).

Insofar as guilt (a guilty conscience) is concerned, Derrida appears to accept the notion of guilt existing before the crime (rather than accompanying it as is supposed by criminal law), but for him this is not to be traced back to the Oedipus complex. At

\footnotetext{
10 Derrida's stance towards the Oedipus complex is set out in more detail in The Post Card (Derrida 1987) where he notes, inter alia, that the unconscious generated by the restricted economy of the Oedipus complex is inscribed within what can be referred to as a 'general economy'.

11 See Freud (2001 XIV, p. 333): 'We must remember...that parricide and incest with the mother are the two great human crimes, the only ones which, as such, are pursued and abhorred in primitive communities'.
} 
stake is again the force of self-destruction (primary masochism/sadism) which Freud invokes in Beyond the Pleasure Principle, which doubles as a kind of ethics or prohibition preceding the guilt, thus making the latter possible (Derrida 2017, p. 126). This 'ethics' entails a hyper-ethical demand or duty of absolute hospitality, the pure gift, forgiveness, which we are always already guilty of not complying with (Derrida 2001, pp. 43-44; 2008, p. 52). ${ }^{12}$ Guilt presents itself to psychoanalysis as Oedipal in nature, because it views the unconscious in economic terms (Derrida 2009, p. 245; 2018 , p. 44). Criminal law and its conception of guilt/fault is itself derived from this hyper-ethical demand. ${ }^{13}$

Freedom in the Kantian sense cannot therefore be accepted without qualification. This is because of the inevitable merging of the noumenal and the phenomenal, or in other words, the impossibility of man fully overcoming his phenomenal nature. ${ }^{14}$ In Kant's Metaphysics of Morals there is an implicit recognition of this merging in the discussion of two exceptions to be made to the imposition of the death penalty in the event of murder: maternal infanticide in the case of an illegitimate child, and the killing of someone in a duel in defence of one's honour (Kant 2015, 6:336-337). For Kant $(2015,3: 337)$ these are indeed killings, but not strictly speaking murders. He notes in this respect a disjuncture between the incentives of honour in the people (subjectively) and the measures that are (objectively) suitable for its purpose', which can be generalised (Derrida 2014, p. 127). There is clearly an acknowledgement here of a remainder of the state of nature, or of homo phaenomenon, which can only be overcome when the ideal state of a congruence between the subjective and objective has been reached (and then the death penalty would no longer be required) (Derrida 2014, p. 127). These exceptions, as Derrida (2014, p. 125) notes, both undermine and lay bare the law on the death penalty. This does not however mean that Derrida prescribes to a complete (psychic) determinism, ${ }^{15}$ as can also be seen in the reference above to a hyper-ethical demand of absolute hospitality. One can however never be sure that one complied with this command, that one was really 'responsible' in the sense required here (Derrida 1997b, pp. 68-69; 2017, pp. 126-127; Derrida and Roudinesco 2004, pp. 52-53).

\footnotetext{
${ }^{12}$ See e.g. Derrida (2001, p. 22): 'I always have to be forgiven, to ask forgiveness for not giving, for never giving enough, for never offering or welcoming enough. One is always guilty, one must always be forgiven the gift.'

13 See also Derrida (2009, pp. 39-43) where he, in a reading of Hobbes's Leviathan, analyses the notion of fear as the basis of both crime and compliance with the law, as well as ultimately, for the establishment of the state. It is not the fear of one's fellow man that is at stake here, but fear for the self, for the wolf inside the self. For analysis, see De Ville (2012).

${ }^{14}$ In Derrida and Roudinesco (2004, p. 48) Derrida notes that the word freedom 'often seems to me to be loaded with metaphysical presuppositions that confer on the subject or on consciousness- that is, on an egological subject-a sovereign independence in relation to drives, calculation, economy, the machine'.

${ }^{15}$ See Derrida and Roudinesco (2004, pp. 48-49, also at p. 58) where Derrida speaks of 'an excess of play in the machine'.
} 


\section{The Sovereign's Right to Punish ${ }^{16}$}

The analysis in the section above places in question the notion of 'guilt' or 'fault' as it operates in criminal law, which, if accepted, would necessarily imply that there is no justification for punishment. However, let us look nonetheless at the notion of punishment in Kant, and Derrida's analysis thereof in the Seminars to further underline this absence of justification. In the section dealing with the 'Right to punish and to grant clemency', Kant (2015, 6:331-337) sets out his views on the right of the state, the ruler (des Befehlhabers), to punish the wrongdoer. Kant defines the right to punish as 'the right a ruler has against a subject to inflict pain upon him because of his having committed a crime' (2015, 6:331). The ruler cannot however himself be punished; one can only withdraw from his dominion. In the appendix to the Doctrine of Law, Kant further elaborates on the concept of the right to punish $(2015,6: 363)$. He starts off by noting again that ' $[t]$ he mere idea of a civil constitution among human beings carries with it the concept of punitive justice belonging to the supreme authority (der obersten Gewalt)'. In his analysis of this section, Derrida (2017, p. 87) points out that this power-to punish, but not to be subject to the law oneself-is fully in accordance with Carl Schmitt's definition of the sovereign as he who decides on the exception as well as with Benjamin's description of the state as ensuring that it holds the monopoly on violence. ${ }^{17}$ A number of limitations on sovereign power have of course been imposed in recent years, including term limits of Heads of State, the possibility of impeachment, as well as the possibility of prosecution (Derrida 2017, pp. 88-89). One could add the limitations imposed on sovereignty by transnational and international laws, the possibility of judicial review, which exists in certain jurisdictions in relation to these sovereign (prerogative) powers, as well as the abolition of the death penalty in the majority of countries around the world. Derrida (2014, pp. 2-3) specifically emphasises the importance of visibility in relation to the imposition of the death penalty, whether or not in the form of a public spectacle. It is in seeing the condemned being put to death that the nation-state sees itself, becomes aware of its own sovereignty, and thus returns to itself, in what Derrida refers to as its ipseity (ipse = self; which contains within itself the idea of force, power and mastery).

As he does in a number of other texts, Derrida in the Death Penalty seminars closely analyses the concept of sovereignty, here specifically the sovereign right to punish. The aim of this deconstruction is not to abolish sovereignty, but to show its phantasmatic nature, and in this way to expose its actual structure (Derrida 2017, pp. 171-172). In Volume I, this takes place with reference to the notion of cruelty, and in Volume II, with reference to Freud's primal horde. The focus in the present section will be on the relation between sovereignty and cruelty, specifically in Kant. Of relevance here is Nietzsche's reading of Kant in the Genealogy of Morals as well as Freud's analysis of the death drive in Beyond the Pleasure Principle.

\footnotetext{
16 For reasons of space, Kant's reflections on the granting of clemency will not be discussed here.

17 See also Derrida (2014, pp. 83-88).
} 
In the Genealogy of Morals Nietzsche (2003a, p. 41) famously refers to Kant's categorical imperative as reeking of cruelty. ${ }^{18}$ At stake here is Kant's reference to the law of punishment/penal justice (das Strafgesetz), and more specifically of the obligation to impose the death penalty in the case of an unlawful killing, as a categorical imperative (Kant 2015, 6:336). The latter is of course to be distinguished from a hypothetical imperative, which is subject to the calculation of ends and means, and which involves pathological interests, utility (Derrida 2017, p. 90). Kant, as we will see further below, vehemently opposes utilitarian approaches which would either oppose or support the death penalty because of, for example, the greater good of society. In the Doctrine of Law Kant criticises Beccaria who argued in favour of abolishing the death penalty on utilitarian grounds. For Kant, utility and example (deterrence) cannot play any role in relation to the imposition of the death penalty. Man has to be treated as an end in himself, and not as a means towards an end (Derrida 2017, p. 21). Kant speaks in this regard of the interest of pure reason, which would be beyond any empirical or phenomenal interest (Derrida 2014, p. 141). Invoking Nietzsche, Derrida (2014, p. 141) however raises the question of the interest lying behind the pure interest or the disinterest of pure reason. Following upon his comment on the categorical imperative, Nietzsche (2003a, p. 73) enquires into the alleged disinterest of assessments of the beautiful in Kant's Critique of Judgment: "That is beautiful," says Kant, "which pleases without interesting." Without interesting!'. Nietzsche here pokes fun at Kant's statement about naked female statues which, if they are beautiful, can be looked at by men without interest. Nietzsche therein detects a resistance to sensuality on the part of the philosopher in general, whilst being attracted by the beautiful (Nietzsche 2003a, p. 75). The philosopher typically negates the world, and adopts a stance of hostility towards life, and towards the senses (Nietzsche 2003a, p. 83). In the ascetic ideal the philosopher finds his faith as well as his power, his interest; his right of existence can be said to lie in this ideal (Nietzsche 2003a, p. 83). By positing this ideal, the ascetic philosopher shows a disgust in himself, the world, and all of life, causing himself 'as much hurt as possible out of a pleasure in hurting - perhaps [his] one and only pleasure' (Nietzsche 2003a, p. 84). Nietzsche concludes that at stake here is a certain tendency of life to turn against itself:

It must be a necessity of the first order which makes this species, hostile, as it is to life, always grow again and always thrive again.-Life itself must certainly have an interest in the continuance of such a type of self-contradiction. For an ascetic life is a self-contradiction: here rules resentment without parallel, the resentment of an insatiate instinct and ambition, that would be master, not over some element in life, but over life itself, over life's deepest, strongest, innermost conditions; here is an attempt made to utilise power to dam the sources of power.... All this is in the highest degree paradoxical: we are here

\footnotetext{
${ }^{18}$ See also Derrida (2017, pp. 204-206) on the causal relation which Reik (1959, pp. 408-430) places between idealism and cruelty.
} 
confronted with a rift that wills itself to be a rift, which enjoys itself in this very suffering... (Nietzsche 2003a, p. 84)

The ascetic ideal is thus for Nietzsche not at all characterised by an absence of interest, but 'in fact, [by] the strongest and most personal interest of all, that of the victim of torture who escapes from his torture' (Nietzsche 2003a, p. 74; Derrida 2014, p. 144). This idea is later also to be found in Freud (2001, VII, pp. 157-160; XVIII, pp. 53-54), who traces the phenomena of sadism and masochism back to an originary sadism/masochism, i.e. a self-destructive drive. Applying these insights to Kant's stance on punishment, specifically the death penalty, Derrida contends that '[j]ust as much as the abolitionist [this is Baudelaire's argument: those who oppose the death penalty feel guilty of a mortal sin and are scared of losing their own necks (Derrida 2014, pp. 129-130)], the proponents of the death penalty as categorical imperative are afraid for themselves [ont peur pour eux]'; they 'seek to be delivered from a condemnation or from the threat of a verdict-and from the torture which this threat constitutes' (Derrida 2014, p. 145, translation modified).

Derrida remains, however, interested in and seeks to explore further the notion of the cruelty of the categorical imperative, specifically in its relation to life and sovereignty. Nietzsche finds it particularly problematic that Kant's cruelty is a 'cruelty that does not speak its name, a hypocritical cruelty that gives itself airs of keeping its hands clean' (Derrida 2014, p. 148). ${ }^{19}$ Central here is Nietzsche's second essay in the Genealogy of Morals where he writes about the infliction of pain through the ages in ensuring that man gains a memory. From this Nietzschean genealogy of cruelty, Derrida (2014, p. 149) concludes that cruelty is the essence of life: 'Life knows how to make itself suffer in order to keep itself, and to keep itself from forgetting, to keep itself in memory'. At stake in cruelty, as Derrida (2014, pp. 155-156, 163-164) further points out, is the inevitability of a certain pleasure in causing suffering through the exercise of power, reminding us of Freud's analysis in Beyond the Pleasure Principle of the death drive, and its relation to the drive to dominate as well as to sadism and to masochism (Derrida 1987, pp. 367-368, 404-405; 2014, pp. 159-160). Kant therefore cannot escape from cruelty, and neither can Beccaria, seeing that cruelty has no opposite (e.g. non-cruelty) (Derrida 2014, pp. 147-148). ${ }^{20}$ Life is in other words cruel in itself, in order to maintain itself. Therefore there are only 'different ways, different modalities, different intensities, different values (active or reactive) of being cruel, only a differance, with an $a$, in cruelty, a differant cruelty' (Derrida 2014, p. 168). ${ }^{21}$ Should one thus, Derrida asks, simply accept

\footnotetext{
19 See likewise Reik (1959, p. 473) who, invoking Freud, notes that 'punishment not infrequently offers, to those who execute it and who represent the community, the opportunity to commit, on their part, the same crime or evil deed under the justification of exacting penance'.

20 One cannot therefore make a convincing argument either for or against the death penalty simply in the name of cruelty. We know that Beccaria for example, argued for the abolition of the death penalty, as it was not cruel enough; see Derrida (2014, pp. 160-161). On the other hand, proponents of the death penalty at times seek through new inventions to make executions more humane and less cruel.

21 See likewise Foucault (1991, pp. 15-16) who points to the bodily pain of imprisonment and the trace of torture that remains in modern systems of punishment, even though the primary site of concern has moved towards the offender's soul.
} 
cruelty as a fatal misfortune (whatever one does, it will be cruel), or alternatively (and this alternative splits in two), continue to believe, contra Nietzsche, in the possibility of not being cruel, that is, "to proceed from a place that is still protected by some innocence or some immunity or indemnity...or else [the second alternative] is it already, already and always, contaminated, overtaken by the contagion of this cruelty that it comprehends in advance?' (Derrida 2014, p. 168).

The relation between sovereignty and cruelty is further explored by Derrida in 'Psychoanalysis searches the state of its soul'. There Derrida (2002, pp. 241, 258) links together very explicitly sovereignty, the drive to mastery (identified by Freud 2001 XVIII, p. 16) and cruelty. The latter, Derrida contends, is indissociably linked to the drive for sovereign mastery. There is no escape from this drive: the drive for sovereign power cannot be eradicated. Yet this drive always already involves a reaction to, a binding of, a certain force beyond measure (Derrida 1987, pp. 399-404). The latter arguably is another name for the impossible unconditionality that Derrida (2017, p. 172) has in mind as the condition of possibility of and a certain beyond to sovereignty and cruelty. At stake here for Derrida (2014, p. 255) is another kind of interest than or another figure of interest compared to the disinterest which Kant for example speaks of, as well as of the other interests at stake in favour of and against the death penalty. The interest, as will appear from the discussion below, is an 'interest', if one can call it such, in the incalculability of the 'to come', which is conditioned by my finitude (Derrida 2014, p. 256). The death penalty, on the other hand, seeks to master this incalculability by seemingly putting an end to finitude, making the instant of death calculable (Derrida 2014, p. 258).

\section{The Purpose of Punishment and Political Theology}

Insofar as the purpose underlying punishment is concerned, Kant, as we saw, rejects any kind of utilitarian justification. Punishment cannot be inflicted for the good of the criminal or that of society, but only because the criminal committed a crime. According to Kant $(2015,6: 331)$ the law of punishment is a categorical imperative. Applying utilitarian principles in this context would, according to Kant, mean that the criminal is treated as a means to an end and not as an end in himself. Justice here stands central for Kant, and it would be thwarted should any kind of means-ends argumentation be applied in this respect. This rejection by Kant of utilitarianism applies specifically to the death penalty, both in opposition to and in support thereof (Derrida 2017, p. 42). The penalty itself must likewise be an end in itself and not a means towards an end (Derrida 2017, p. 39). The punishment is in other words not supposed to serve any purpose, and even if it serves no purpose, it must still be imposed (Derrida 2017, p. 39). This again applies specifically to the death penalty, which according to Kant has to be imposed on someone who was sentenced to death even if it would serve no purpose (e.g. in an island society which decides to disseminate). For Kant, punishing someone does not amount to disposing of that person or to do with him as one pleases by instrumentalising him (Derrida 2017, pp. 41-42). Punishment is for Kant about respecting that person, honouring him as someone 'worthy of being punished because his act is punishable' (Derrida 2017, p. 41). It is 
thus for Kant about respect, respecting the dignity of the person being punished 'and not because the punishment will repair a harm or serve as a deterrent or an example or will ensure the security, the happiness, and the well-being of a society' (Derrida 2017, p. 40; Höffe 2014, p. 241). Kant further distinguishes between the innate personality and the civil personality: the innate personality, dignity, cannot be lost whatever the crime, but the civil personality can be lost (Derrida 2017, p. 90).

We saw above that Kant posits a link between the death penalty, man's dignity, his reason, his ability to raise himself above his pathological interests and above animal life, his being an end in himself and not a mere means to an end (Derrida 2017 , pp. 25-26). The death penalty as inscribed in law thus raises the subject above life itself (Derrida 2017, pp. 26, 95-96). Derrida (Derrida 2017, pp. 26-27) invokes in this context the link identified by Benveniste between honour and punish (having the same etymological root: time $)$ and compares this with the link posited by Kant between the death penalty and human dignity. Man, as we saw above, belongs to two worlds. It is because of his belonging to the noumenal world that man feels within himself respect and reverence for the moral law. Should one abolish the death penalty, one would give up on that which constitutes the honour and dignity of man. Respect for dignity is thus worth much more than life itself (Derrida 2014, p. 116). Life, the right to life, cannot be an absolute principle. Whereas homo phaenomenon clings to life, homo noumenon must raise himself above this by providing for the death penalty in his laws (Derrida 2014, p. 124). This demand is also imposed by justice, which must be beyond calculation and not tied to a price, justice being worth more than life (Derrida 2014, pp. 270-271; 2017, 40). One could say that for Kant, a code of law that does not have the death penalty would not be a code of law (Derrida 2014 , p. 116). The idea of law for Kant is thus inherently tied to the dignity of man, to his sovereignty, to the notion that that there is something more worthy than life. Life as such is in other words not sacred, and 'must be liable to be sacrificed' (Derrida 2014, p. 116). To fail to inscribe the death penalty in law would be unworthy of human dignity; it would amount to a 'return to the state of nature and animality' (Derrida 2014, p. 130).

What we find in the above analysis of Kant is a certain conception of man, of what is proper to man, which we also find in some or other form throughout the whole history of Western philosophy. At stake in these conceptions of man is the traditional distinction between man and animal and which in the case of the death penalty specifically (but also elsewhere) aligns philosophy (from Plato to Heidegger) with political theology (Derrida 2017, p. 248; Derrida and Roudinesco 2004, p. 147). What is it in man (language, speech, reason) that raises him above the animal, above animal life, above biological life? In Kant, as we saw, this distinction lies in freedom/dignity, which is what is supposedly proper to man. In Plato's thinking, characterised by the distinction between the ideal and the phenomenal world, there is likewise something worse than receiving the death penalty; that is, to be treated like a beast, not to be buried (Derrida 2014, pp. 8-9). For Heidegger, similarly, it is only Dasein who can die; the animal simply perishes. Being-towards-death is thus viewed by Heidegger as proper only to man (Derrida 2017, pp. 209-211, 219).

Kant's notion of dignity clearly has theological overtones and can be described as an immortality beyond life (Trumbull 2015, p. 331), or as life beyond or greater 
than life (Naas 2012, p. 53). This notion of immortality or infinity is in turn aligned to sacrifice: life (human or animal) needs to be sacrificed for the sake of that which is greater than life (Derrida 2014, p. 116; Naas 2012, p. 53). This sacrifice of life moreover provides the condition of possibility for law in Kant (Derrida 2017, p. 245; Derrida and Roudinesco 2004, pp. 142, 145-146). ${ }^{22}$ As Derrida (2017, p. 245) points out, 'Kantian thought is sacrificial through and through; Kantian morality is a sacrificial morality'. (Bloody) Sacrifice, one could perhaps also say, is the older logic, providing the basis for the lex talionis (Goldgaber 2017, p. 3), and it is in turn tied to the theological notion of sin: rather punish the guilty one, than have God punish all (Derrida 2017, p. 255). This sacrificial politics, as Derrida points out, is not restricted to Christianity, or to the Abrahamic religions, but is a characteristic of all cultures (Derrida 2017, pp. 256, 259). Derrida therefore contends that the death penalty only makes sense as long as there is a belief in God and the afterlife. Only then is the final judgment still coming and the death penalty not irreversible (Derrida 2017, p. 253). Secularisation must therefore inevitably lead to the abolition of the death penalty as well as of criminal law, of punishment, of law, and of the state (Derrida 2017, pp. 254, 262-264).

Having exposed the political theology that informs Kant's views on criminal law in general and capital punishment specifically, Derrida, towards the end of The Death Penalty vol. I, outlines the structure of Kant's principled argument in favour of the death penalty. Derrida does so whilst at the same time devising an alternative understanding of life (as survival), which is not informed by political theology. What belongs to life, according to Derrida (2014, p. 256), is not immortality, but 'to have a future, thus some life before it, some event to come'; and moreover, life entails that the moment of death is not calculable. What the death penalty however does is to make the moment of death calculable, amounting to "the interruption of the principle of indetermination, the ending imposed on the calculable chance whereby a living being has a relation to what comes, to the to-come and thus to some other as event, as guest, as arrivant' (Derrida 2014, p. 256). As Derrida (2014, p. 256) points out, it is precisely because my life is finite, that I have this relation to incalculability as to the instant of my death. The death penalty on the other hand appears to deprive me of my finitude, and makes death calculable through all kinds of machines: 'the law, the penal code, the anonymous third party, the calendar, the clock, the guillotine or another apparatus' (Derrida 2014, p. 257). In doing so the death penalty seduces 'fascinated subjects', both those who condemn and at times the condemned (Derrida 2014, pp. 257-258). This is because of the phantasm of the end of finitude, of incalculability, the anxiety before the future, which as we saw, belongs to life. The death penalty thus creates the illusion of infinity; it seems, in the words of Gratton (2014), 'to master the future, to master death, and to put an end to finitude itself' and in this manner fascinates us: "what we are dreaming of, that is, what in a certain way we

\footnotetext{
${ }^{22}$ In Derrida and Roudinesco (2004, p. 142) Derrida points out that the death penalty is at the same time transcendental and internal. Whilst it is an element of criminal law, i.e. one punishment among others, it is also external, excluded: the foundation of criminal law, its origin.
} 
desire, namely to give ourselves death and to infinitize ourselves by giving ourselves death in a calculable, calculated, decidable fashion' (Derrida 2014, p. 258).

Proponents of the death penalty (like Kant) thus dream of mastering the future, whereas opponents fight against the calculating decision in the name of an incalculable future (Derrida 2014, p. 258). The force of this phantasmatic truth, as Derrida (2014, p. 258) points out, make it likely that there will always be proponents of the death penalty, and thus also abolitionists.

\section{The Measure of Punishment}

We saw above that for Kant the ius talionis lies at the basis of criminal law, and punishment must consequently be meted out in line with this principle. Both Nietzsche and Reik, as we will see in more detail below, object to the ius talionis in Kant. For Nietzsche there is no equivalence, no common measure between injury and pain, between wrong and suffering. He then traces the origin of the belief in such an equivalence to commercial law, i.e. to the idea of credit, duty, debt, sale, exchange, the market. The equivalence was in other words invented; it does not exist, has never existed, and will never exist (Derrida 2014, pp. 151-152). For Reik on the other hand, Kant is here simply rationalising the talionic drive of vengeance that is lodged in the unconscious (Reik 1959, p. 290; Derrida 2017, pp. 178-179). Derrida defends Kant against both Nietzsche and Reik. Although the ius talionis is usually associated with passionate or pathological vengeance, Derrida (2017, p. 91) points out that for Kant, the ius talionis is instead about a principle of calculation that avoids vengeance. It is in other words about equity or equality: the punishment, which is to be meted out by a third party, i.e. the state, instead of by the victim, should not escalate into an 'uncontrolled unleashing of vengeance' (Derrida 2017, p. 91). There is however another dimension to the ius talionis, which Derrida points to, partly in response to Nietzsche. The Latin talio, as Derrida (2017, p. 102) notes, derives

from talis (tel [such]), a demonstrative of quality (from tel [such] one moves to quel [which or what]: he has committed such a crime [il a commis tel crime], he will be punished in such a way or in an equal way [il sera puni de telle ou d'égale façon]), [so] that the enigmatic passage from quality to quantity under the schema of equality or equity is already inscribed in the word.

According to Derrida the same thing happens in Kant because ultimately it is for Kant about dignity, honour and respect, which have no price, that is, which are not calculable.

When Kant (2015, 6:332) therefore says that the same 'undeserved evil you inflict upon another within the people, that you inflict upon yourself', at stake are two equivalences which actually escape calculation. The first is the evil done to another which is felt within the self (of the wrongdoer); and the second, between the wrongdoer and the victim, two persons of equal worth and dignity. The equality in the second instance does not enable calculation, because at stake are "two "without measures," two measureless or immeasurable dignities' (Derrida 2017, p. 92). The incalculability of the first equivalence stems likewise from such immeasurable 
dignity, leading to the 'immediate, rational interiorization of the suffering or the evil inflicted upon the victim' (Derrida 2017, p. 92). According to Kant (2015, 6:332), as we saw, it is not the victim, but a third party, i.e. a court, that must determine the exact punishment ('the quality and the quantity of punishment') with reference to the ius talionis. Derrida (2017, p. 93) reads this as law being subject to a kind of ethics, the ethics of the talio. In Derrida's reading, quality dominates here, and it is shown by all the examples which Kant gives under this heading: an insult, theft, murder, and treason. Derrida (2017, p. 102) summarises the effect of Kant's examples as follows:

Everything is played out in the half-light of the relation between the quantitative and the qualitative, the calculable and the incalculable. And what Kant seems to prescribe, or what Kant seems to describe as to what the law [le droit], justice, and the law [la loi] should prescribe, is like a calculation of the incalculable, a rational and impersonal calculation of what eludes calculation... 23

In responding to Reik's accusation against Kant, Derrida (2017, pp. 183-184) similarly reads Kant's statement regarding the talionic law-that it is 'by its form always the principle for the right to punish since it alone is the principle determining this idea a priori (not derived from experience of which measures would be most effective for eradicating crime)' (Kant 2015, 6:363)—as giving 'the idea of calculation', but that it 'is not itself originally calculable'. ${ }^{24}$ There is thus here a distinction and a tension between a pure talionic law, or an Idea of punitive justice which remains foreign to calculation, which remains foreign to any unconscious drive (Reik/Freud) or calculation of assurances (Derrida 2017, pp. 184-185), on the one hand, and on the other, (penal) law, which remains calculable. This statement of Kant, which appears in the Appendix, precedes the discussion of the particular difficulty of applying the talionic law, that is, of determining the appropriate sentence for certain 'sexual' or 'perverse' crimes where it would be either impossible or a crime against humanity to do the same unto the criminal as he had done unto another. The examples which Kant gives are of rape, pederasty and bestiality. The punishments that Kant prescribes are castration (for rape and pederasty) and expulsion from civil society in the case of bestiality. These punishments, Kant (2015, 6:363) says, come closest to the ius talionis, if not in the letter, then at least in its spirit. Derrida (2017, p. 109) notes that a cutting is at stake in both types of punishment: in the first, the cutting is literal, in the second, the citizen is cut off from civil society. Whereas the tendency in psychoanalysis is to see castration as central, showing thereby its privileging of the phallus and thus its phallocentrism, and death as secondary (Derrida 2017, pp. 228-230), Derrida (2017, p. 130) switches these concepts around

\footnotetext{
${ }^{23}$ Translation modified. See likewise Derrida (2017, p. 140) on the ius talionis as 'the necessary, the ineluctable passage from quality to quantity, from the in-calculable or the non-calculable to the calculable', and at p. 144 .

24 Derrida relies here on the distinction in Kant between form and content, the latter which would e.g. point to the 'interests' at stake in other discourses on the death penalty.
} 
and reads Kant's two proposed punishments as both signifying death (or the death penalty).

Derrida (2017, p. 158) further finds a certain remorse or discomfort on the side of Kant in having to calculate the non-calculable in these three instances. It is interesting, significant and not coincidental that it is specifically sexual crimes which Kant mentions here for which it is so difficult to find an equivalent punishment or rather chastisement. For the punishments prescribed are indeed attempts to chastise, to make chaste, words with 'a kind of sexual family likeness, a sexual subconscious [subconscient sexuel] lodged in the word' (Derrida 2017, p. 167). The chastisement at stake here, Derrida (2017, p. 168) further notes, 'awakens or alerts us to a sexual world in which all this penal law and talionic law take on meaning'. It further raises the question 'whether talionic law in general is not, first of all, in its very paradigm, a law of sexual exchange and substitution. Properly or figuratively speaking' (Derrida 2017, p. 168). Derrida (2017, p. 169) points here to the Biblical 'an eye for an eye and a tooth for a tooth', and the fact that eyes and teeth in psychoanalysis are understood as phallic substitutes. He raises the following hypothesis, which we touched on earlier:

According to this hypothesis, the sexual crime would first be, in a manner at once paradigmatic and archaic, the very mainspring of talionic law, the essence or the element of every crime and every punishment, of every castigation, of every castigating exchange in general. This is because the essence of crime, its quasi-transcendental mainspring or motivation, would be what is called-at any age, at the time of the desire, or at the time of the act - sex (Derrida 2017, p. 169). ${ }^{25}$

In the talionic law we thus appear to again come across the stricture of différance, the death drive, pleasure, with all their abyssal detours. The penal justice of Kant, as Derrida (Derrida 2017, p. 184 n. 29) points out in line with this stricture, specifically in relation to the death penalty, serves no purpose and is not supposed to serve any purpose; it amounts to an incalculable madness, as can be seen inter alia from the island example. ${ }^{26}$ At stake in Kant's notion of justice can therefore in a sense be said to be a gift which gives measure or calculation, but which itself remains foreign to the calculable (Derrida 2017, p. 184). ${ }^{27}$

\footnotetext{
25 'Sex' is of course not here to be understood in the ordinary sense, or in an Oedipal sense, as indicated earlier.

${ }^{26}$ Further complicating Kant's stance on the death penalty is his statement that the (execution of the) death penalty 'must still be freed from any mistreatment that could make the humanity in the person suffering it into something abominable', Kant (2015, 6:333). As Derrida (2014, p. 273) points out, this requirement is impossible to comply with, making 'both the condemnation to death and especially its execution' forever impermissible. Kant would thus de lege be a proponent of the death penalty, but de facto an abolitionist. See also Derrida and Roudinesco (2004, p. 152).

${ }^{27}$ It can be noted in this regard that for Heidegger (similar to what Kant seems to be saying here), death 'is the measure because it gives the measure, and giving the measure, it is not measurable'. Derrida (2017, p. 156).
} 


\section{Conclusion}

How should law, which is inevitably conditional and calculating, respond to the challenge posed by Derrida to take account of the unconscious and of the symptom in relation to specifically criminal law in respect of act, desire and age? What should, in other words, in view of Derrida's analysis, happen with the foundational principles, concepts and stratagems of criminal law: actus reus, mens rea, punishment? Let us at this point look again at some of the more specific questions raised in Derrida's analysis under the headings of responsibility and punishment: First, responsibility - how can someone be found guilty of a crime if it cannot be proved that the person had the requisite freedom to decide what to do in the circumstances, i.e. if there indeed is no such thing as freedom in the Kantian sense; if we can never be sure that we are capable of or have in fact acted responsibly; and if the age of a person always consists of a variety of ages? Shifting the focus, how is the notion of guilt accompanying the crime reconcilable with a radically forgotten guilt because of a 'sexual desire' or 'pleasure beyond pleasure', which we all share and are subject to; if the wrongdoer, by committing a crime, in fact is confessing to an originary crime and guilt that existed beforehand; if the wrongdoer seeks hetero-punishment so as to obtain relief from an overbearing sense of guilt; when we all harbour aggressive and murderous thoughts, at least in the unconscious? Secondly, punishment-how can we continue to impose punishment as a society, if this is inevitably motivated by a cruel, sovereign drive; if the notion of punishment (especially the death penalty) is intrinsically tied to political theology, to bloody sacrifice, to the instinct of self-preservation of a society? (Reik 1959, p. 290). How do we measure punishment in a justifiable way, when it involves a calculation with the incalculable? Thirdly, in respect of both responsibility and punishment, is a break possible with the circle of economic exchange which so clearly characterises criminal law, making the latter an active part of the circle, being invoked by wrongdoers, as well as by the public in general, who seek punishment in its variety of forms (auto-, hetero-, yet unavoidably cruel)? These are uncomfortable questions which challenge the very foundations of criminal law, both its assumptions and justice.

Seeking to minimise the cruelty of punishments (abolition of the death penalty and corporal punishment, prison reforms, alternatives to incarceration, etc.), under the influence of human rights declarations, are undoubtedly progressive advances. ${ }^{28}$ Even more so would be the replacement of hetero-punishment with confession, with auto-punishment, as Reik (1959, pp. 297-298) proposes. We already see isolated examples of the latter in the Truth and Reconciliation process of a country like South Africa, where legal punishment was for a period suspended on the condition of a full disclosure of all the relevant facts relating to the (political) crime, as well as in the recent 'confessions' by heads of state or heads of government of atrocities committed in the past of a nation. With attempts to minimise cruelty, with 'amnesty' (subject to certain conditions, and serving the aim of 'national reconciliation'), as

\footnotetext{
28 Something similar can be said of movements towards decriminalisation of e.g. prostitution, homosexuality, abortion, drugs and petty offences.
} 
well as confessions which serve certain political and economic interests, we however remain within the circle of economic exchange, of 'forgiveness' viewed in economic (Reikian) terms (Reik 1959, p. 425). 'In principle', as Derrida (1997a, p. 27) notes, 'there is no limit to forgiveness, no measure, no moderation, no 'to what point?' At stake in this unconditional forgiveness is clearly something excessive, mad, hyperbolic (Derrida 1997a, p. 39), something that lies beyond the space of the legal order, beyond punishment and penalty, beyond legal calculation, even beyond the sovereign power to pardon (Derrida 1997a, p. 45; 2001, pp. 25, 33). Forgiveness in this unconditional sense goes beyond the reciprocity implied by repentance, atonement, reconciliation, and confession (Derrida 2001, pp. 27-29). Today, in the twenty-first century, we still live in the age of Enlightenment, which is also the age of deconstruction, the age in which sovereignty, despite recent attempts at push-back, is increasingly showing signs of dissolution. We see a certain Kantian 'progress' here, a Reikian 'advance', ${ }^{29}$ which signals the end of criminal law, of punishment, and thereby also of the ordinary course of historic temporality. It is in the name of the (French) Revolution, the (Kantian) Enlightenment, as an event that remains to come, in the name of an uneconomical and unconditional forgiveness, in the name of absolute hospitality, the perfect gift, justice, that criminal law reform must be accelerated, i.e. economic exchange should be broken with, to become more hospitable, forgiving, giving. A negotiation is in other words called for between the unconditional and the conditional (Derrida 2001, p. 58). This demand remains a categorical imperative, even though law may never be able to escape from economic circularity.

Acknowledgements Funding provided by the National Research Foundation and the Alexander Von Humboldt Foundation is gratefully acknowledged.

\section{References}

Derrida, Jacques. 1987. The post card: From Socrates to Freud and beyond. Chicago and London: The University of Chicago Press.

Derrida, Jacques. 1997a. Cosmopolitanism and forgiveness. London: Routledge.

Derrida, Jacques. 1997b. Politics of friendship. London: Verso.

Derrida, Jacques. 2001. To forgive: The unforgivable and the imprescriptible. In Questioning God, ed. John D. Caputo, Mark Dooley, and Michael J. Scanlon, 21-51. Bloomington: Indiana University Press.

Derrida, Jacques. 2002. Without alibi. Stanford: Stanford University Press.

Derrida, Jacques. 2008. The gift of death, $2 \mathrm{~d}$ ed., and Literature in secret. Chicago: The University of Chicago Press.

Derrida, Jacques. 2009. The beast \& the sovereign, vol. I. Chicago: The University of Chicago Press.

Derrida, Jacques. 2014. The death penalty, vol. I. Chicago: The University of Chicago Press.

Derrida, Jacques. 2017. The death penalty, vol. II. Chicago: The University of Chicago Press.

Derrida, Jacques. 2018. Before the law: The complete text of préjugés. Minneapolis: University of Minnesota Press.

${ }^{29}$ See Reik (1959, p. 296) and Kant (1979, p. 151). 
Derrida, Jacques, and Elisabeth Roudinesco. 2004. For what tomorrow...A dialogue. Stanford: Stanford University Press.

De Ville, Jacques. 2012. Deconstructing the leviathan: Derrida's The Beast and the Sovereign. Societies 2(4): 357-371.

Foucault, Michel. 1991. Discipline and punish: The birth of the prison. London: Penguin Books.

Freud, Sigmund. 2001. The standard edition of the complete psychological works of Sigmund Freud, vol. I-XXIV. London: Vintage.

Geismann, Georg. 2012. Kant und kein Ende Bd 3. Würzburg: Königshausen \& Neumann.

Goldgaber, Deborah. 2017. Review of Jacques Derrida, the death penalty, Volume II. Notre Dame Philosophical Reviews. https://ndpr.nd.edu/news/the-death-penalty-volume-ii/. Accessed 3 March 2019.

Gratton, Peter. 2014. Death and Derrida. Berfrois. https://www.berfrois.com/2014/04/death-and-derridaby-peter-gratton/. Accessed 3 March 2019.

Höffe, Otfried. 2014. Immanuel Kant. München: C.H. Beck.

Kant, Immanuel. 1979. The conflict of the faculties. New York: Abaris Books.

Kant, Immanuel. 1996. Practical philosophy. Cambridge: Cambridge University Press.

Kant, Immanuel. 2015. The metaphysics of morals. Cambridge: Cambridge University Press.

Naas, Michael. 2012. The philosophy and literature of the death penalty: Two sides of the same coin. The Southern Journal of Philosophy 50: 53.

Nietzsche, Friedrich. 2003a. The genealogy of morals. New York: Dover Publications.

Nietzsche, Friedrich. 2003b. Thus spoke Zarathustra. London: Penguin Books.

Reik, Theodor. 1959. The compulsion to confess. New York: Wiley.

Schmeiser, Susan R. 2007. Furnishing guilt. American Imago 64(3): 317-337.

Trumbull, Robert. 2015. Derrida and the death penalty: The question of cruelty. Philosophy Today 59(2): 317-336.

Publisher's Note Springer Nature remains neutral with regard to jurisdictional claims in published maps and institutional affiliations. 